\title{
A Case for Private Sector Participation in Higher Education Development in Africa with Specific Reference to Recovery in a Globalized Economy
}

\author{
Osuji Celestina N. ${ }^{1,}{ }^{*}$, R. M. Mafara ${ }^{1}$, Becky Chagbe ${ }^{2}$ \\ ${ }^{1}$ Federal University Gusau [* Corresponding author: ugwujicelestina@gmail.com], ${ }^{2}$ Federal \\ College of Education
}

\begin{abstract}
This paper notes that while globalization is presenting opportunities for economic growth and development, it is also presenting constraints against the same. Subsequently, the authors argue, there is need to develop (through higher education) the knowledge, skills and attitudes required to harness the opportunities globalization is offering whilst avoiding the challenges that it is posing. However, in Africa, the reach and effectiveness of the public education system are limited in various ways. Therefore, the authors recommend increased involvement of the private sector in the higher education sector as a panacea for dealing with some of the gaps in public higher education.
\end{abstract}

Keywords: Privatization, Globalization, Economic recovery.

\section{$1 \quad$ Introduction}

No country rises above the standard and quality of her education system. According to Gbamanja (1977), education is the tool for achieving desirable changes. Oni (2004) notes that a functional curriculum is crucially required for human capacity development, wealth creation, employment generation and value orientation. Education is the pivotal springboard for economic and social development. This means that a country's development is a function of its standard of education. This is because the growth and development of any country is highly dependent on the available human resources that will tackle the country's challenges. Education plays a vital role in promoting socioeconomic growth, with a range of positive outcomes like improved health and better livelihoods. UNESCO $(2010,2014)$ demonstrate that education contributes towards pursuit of the Millennium and Sustainable Development 
Goals with each additional year of schooling resulting into a $10 \%$ average increase in an individual's earnings, raises average annual GDP growth by $0.3 \%$ and ultimately contributes to a more inclusive and productive society.

Access to education has dramatically improved throughout Africa (UNESCO, 2010). An increase of $80 \%$ has been observed at the higher education level alone. Despite this increase, however, Africa is still lagging behind the OECD countries' levels. Economic gaps also remain widespread. According to Watkins (2013), only 12\% of eligible youths on the continent are likely to receive tertiary education. The issues compound further with the youth bulge and enormous funding gap. All this points to an urgent need to direct attention towards education. There must be concerted plans and investments in education. However, the problem is that the governments of most African countries are already squeezed from all ends. They cannot meet the increasing educational needs of their citizens and the private sector has to step in to fill the gaps.

\section{The Present State of Education in Africa today}

Africa is the world's most youthful continent. Today, nearly 50 percent of Africans are under the age of 15. It is well known that Africa's young people are the future leaders and will be the driving force behind sustainable growth across the continent. The world today has become a skill and knowledge based global village and; without mincing words, the development of any country is centred on the people's ability to think, create, innovate, invent, transmit and utilize new knowledge that is, the quality of its workforce. It is only highly skilled and trained workforce that can tap from it.

So, what exactly can we say about the position of education now in Africa? Can Africa boast of these? What do we have on our report card? At the higher education level, the continent needs to evolve to provide the right education and training for jobs for today's workforce. There is a severe mismatch still existing between the skills of young African workers and the skills that employers need for today's global workforce. According to UNESCO and Word Bank Key Statistics, only 6 percent of young people in Africa are enrolled in higher education institutions compared to the global average of 26 percent. The good news is that universities in many African countries are experiencing a surge in their enrolment. Between 2000 and 2010, higher education enrolment was more than doubled, increasing from 2.3 million to 5.2 million. Overcrowding in lecture halls at some Africa universities is becoming all too common. Statistics show that on the average, there are 50 percent more students per professor in African universities compared to the global average. In 2008, about 223,000 
students from Africa were enrolled in tertiary education outside of their home countries, representing 7.5 percent of the total global number of students who study outside of their home country. Private higher education is one of the fastest growing education sectors in Africa. As at 2009, there were around 200 public universities and 468 private higher education institutions on the African continent. Comparatively, there are 1700 public universities and nearly 2500 private universities (4- and 2-year universities) in the U.S. alone. A one-year increase in average tertiary education levels would raise annual GDP growth in Africa by 0.39 percentage points, and eventually yield up to a 12 percent increase in GDP.

Then, what is the quality of education in Africa like? What about funding and producing skilled workforce for 21 st century jobs. Realizing the correlation between education and socio-economic development, African countries have gradually increased public funding on education by more than 6 percent each year. Africa allocates 5 percent of total GDP of about $\$ 1.5$ trillion to public education expenditure, which is the second highest percentage after North America with a total $\$ 32$ trillion GDP per capita and Europe at 5 percent with a total \$24 trillion GDP per capita. African countries have allocated the largest share of government expenditure to education at 18.4 percent. International donors, on average, finance nearly 6 percent of the education resources of African countries. The total amount of Overseas Development Assistance (ODA) committed to Africa's education sector was \$2.6 billion in 2008, reported The Organization for Economic Co-operation and Development's (OECD) and Development Assistance Committee (DAC). The largest proportion of private funding for education in Africa is generated from individual households. Households contribute about 25 percent of the total national education expenditure, according to UNESCO figures from 16 countries with available data.

Africa being the world's most youthful continent with about 200 million young people between ages 15 and 24, there is need for quality of secondary, vocational/technical and higher education which is often measured by the performance of workers in the labour market as maintained by UNESCO. More so, Africa's working age population of 15 to 64 years continues to grow at a rapid rate. It is projected that by the year 2040, the world's largest labour force will be in Africa with an estimated working age population of 1 billion. But Africa is facing a severe shortage of highly-skilled African workforce. Young people in Africa make up nearly 40 percent of the working-age population, yet 60 percent are unemployed. On average, it will take a university graduate an average of five years to obtain a job in Africa, the case of Nigeria explains it all. Africa's youth population is better educated than previous generations. Based on current trends, 59 percent of ages 20-24 will have a secondary education in 2030, compared to 42 percent today. Going by the numbers, 137 
million young people between ages 20-24 will have a secondary education, and 12 million, a tertiary education.

The big question is: do graduates of African schools possess the skills required for the global market? There is a major gap between the quality of education received and its application to real life and work situations. Researches, innovation, inventions and creativity for African industries and markets have not been sufficiently developed and encouraged by our system. The relevance of the fields of study, the curricula, and the effectiveness of pedagogy for the development needs of African countries and the general quality of programs and graduates remain a big challenge (Ohanyido, 2012).

According to Onyeani (2005), "a people (continent) which regards itself as independent should be able to produce independent thought. Yet, Africans still depend on Europeans, 40 years after "gaining" their independence from their former colonial masters and at a new millennium, to furnish us with books on any subject. Our so-called elites cannot devote enough time to research to duplicate the same research already conducted and articulate it in a language Africans can understand.

According to the United Nations (2016), Africa constitutes the world's poorest region. There is poverty everywhere and the pay of the average man is the lowest in the world." The certificates obtained from African schools are reduce to paper meal tickets. Emphasis moved from skills to paper qualifications. It is really appalling and disheartening that most Africa graduates cannot defend the credentials they parade around. This story needs not to be told about our home country, Nigeria and what is happening today. The brightest ones with high potentials leave the shores of Africa for more developed countries in search of more qualitative education and greener pasture or work. What a brain drain Africa, the land of plenty living on nothing! "Any theory not backed up with practical is a mere story". Africa has a lot of human resource potentials that can fix African economic problems. All that is needed is the right program that will help to harness and tap these potentials. But instead of this to be done, we still prefer inviting the westerners to fix them for us".

\section{The African Economy}

It was reported that Africa as a continent is coming out of years of economic stagnation and emerging as home of seven of the fastest growing economy in the world. In recent years, African economic growth rate started to outpace that of other emerging markets. But today the story is fast changing because of myriads of problems besieging the region's economy as a result of Cheap 
commodities, political uncertainty, epidemics like Ebola and weak banks to the extent that the 'big four' (South Africa, Nigeria, Angola and Kenya) are now affected. The year 2015 was challenging for Africa. Average growth of African economies weakened to $3.6 \%$, down from an average annual $5 \%$ enjoyed since 2000. Total financial flows decreased by $12.8 \%$ and the tax-GDP ratio tumbled to $17.9 \%$, down from $18.7 \%$ in 2014 .

Also, according to the African Development Bank (AfDB) report, 'Africa's economic growth remained resilient in 2015 amid a weak global economy, lower commodity prices and adverse weather conditions in some parts of the continent. Real GDP grew by an average of 3.6\% in 2015, higher than the global average growth of $3.1 \%$ and more than double that of the euro area. At this growth rate, Africa remained the second fastest growing economy in the world (after emerging Asia), and several African countries were among the world's fastest growing countries. There is a forecast by this report that Africa's economic growth will gradually pick up during 2016/17, predicated on a recovery in the world economy and a gradual rise in commodity prices. However, given the vulnerable global economy and the high volatility of commodity prices, this forecast is now uncertain. But today in this 2016, Real Africa GDP is 3.9 and is projected to be 3.7 by 2017 .

Africa's growth slowed down but it is expected to strengthen again as Africa has achieved impressive economic growth over the past 15 years. Average growth of real gross domestic product (GDP) more than doubled from just above $2 \%$ during the 1980 s and 1990 s to above $5 \%$ between 2001 and 2014 . In the past two years, growth has been more moderate with Africa's economies affected by headwinds from the global economy. Average growth of African economies weakened slightly in 2015 to $3.6 \%$ (down from 3.7\% in 2014), about one percent lower than is expected in the AEO 2015. Excluding Libya, where oil production remained volatile, and Africa's overall growth reached $3.7 \%$ in 2015 , down from $4.2 \%$ in 2014 . The AEO macroeconomic outlook for Africa's economy assumes a gradual strengthening of the world economy and a slow recovery of commodity prices.

Against this international backdrop Africa's average economic growth is expected to remain moderate in 2016 (3.7\%), but strengthen in 2017 (to 4.5\%). However, the given the fragile state of the global economic recovery and the high volatility of commodity prices, this forecast in uncertain'. Now, China's decline in investment and rebalanced growth is depressing commodity prices and producing headwinds for Africa. This has a very big blow on African economy. It means that this macroeconomic headwind for net commodity exporters also will result in Africa's external financial inflows to suffer. To survive this therefore, Africa must shift from resources based economy to an infrastructural development and manufacturing production based economy. To be able to achieve this, manpower development through human resource 
development must be invested on because economic transformation hinges on unlocking potential of cities, says the African Economic Outlook 2016.

It is projected that in the next 50 years, Africa will lead other global regions in population growth. Africa's population is young and growing rapidly. Just over 1 billion people live in Africa, half of whom are under the age of 20 . Whilst population growth in other regions has slowed down, Africa's has increased by $2.42 \%$ per year for the past 30 years. By 2050, the African population is forecast to rise to at least 2.4 billion and will continue to grow to 4.2 billion, four times its current size in the next 100 years. Sustained population growth results from mortality rates falling by more than fertility rates. This upsurge of population growth will lead to urbanization and majority of Africans being urban dwellers, thus Africa having the largest mega cities in the whole world. Africa is larger than China, India, United States, Japan, and most of Europe combined and is becoming the next frontier market.

With rapid growing population, increased urbanization, and has the opportunity to transform into a global economic powerhouse given the right workforce. With this, Africa is now the new frontier of economic activities. In 2012, Africa's foreign direct investment (FDI) inflow grew up to USD 50 billion, with much of the investments going to Africa's extractive sector. Africa is emerging as an attractive investment destination and a key market for goods and services. With a working population of 600 million set to double by 2040, overtaking both China and India, and an improving business environment, Africa is poised to become the world's next emerging economy. To turn its economic gains into sustainable growth and shared prosperity, Africa's public and private sectors must work together to connect the continent's markets, deepen regional integration, and adopt reforms that enhance competitiveness in the global economy (African Development Bank Group: Tracking Africa's Progress in figures, 2014).

\section{The Present Global Economic Shift}

The global economic recession of 2000 resulted in countries coming up with economic recovery/austerity policies, reforms and programmes all geared towards cutting down on expenditures and increasing incomes like the G20 of the countries of most advanced economy like USA, China, United Kingdom, Japan, Italy, France, etc. because markets do not correct themselves but rather stimulated by the government of any nation. The world 2030 agenda for Sustainable Development has been facing some challenges in its implementation because of weak global economy which continues to prolong over years now. It should be remembered that global economy went on its 
knees in 2015. Prices of commodities fell and financial volatility keeps increasing in major cities of the world with stumbling exchange rates. This left a whole lot of downward pressure on global economy. To address this impact, ASG Lenni Montiel of UN, explained that many countries, "specifically the Low Developed Countries which rely on commodity exports, will be unable to sustain public spending on health, education, and climate change adaptation and mitigation efforts." We know that the LDCs rely majorly on export of their commodities which averages 16\% of GDP from the commodity industry. With this, UN ASG Lenni Montiel asserted that LDCs will not reach sustainable development goal 8, target 8.1, of 7\% economic growth per year in GDP. Between 2012 and 2013, global economy was distorted as a result of market manipulations by Asian countries especially India and this lead to a shift in global economy, affecting the balance between developed and emerging economies.

Africa's economic growth continues to lose momentum as a result of this, as it is buffeted by global, regional and internal headwinds. While many countries have embarked on a gradual process of economic diversification, with investments increasingly directed towards the manufacturing sector, African continent remains highly commodity-dependent. Given the low level of global commodity prices, export income in many countries dropped sharply in 2015 and may fall further this year, 2016. Many countries suffer from continued shortfalls in infrastructure such as energy supply and health-care facilities, leading to power shortages in countries like Nigeria and complicating progress towards economic and social developments.

In addition, many parts of the continent have suffered from severe drought, which has reduced crop and livestock yield; and severely brought down agricultural production in affected regions. This pushed up inflation, requires higher imports of staple foods, and further reduced export earnings and put pressure on public finances, as basic foodstuffs are widely subsidized. Security concerns also continue to weigh on many parts of the continent, undermining the economic activity. GDP growth for the continent as a whole slowed to 3 per cent last year, and a further moderation to 2.8 per cent is expected in this 2016. This marks a significant downward revision to forecasts reported in the World Economic Situation and Prospects 2016. While a modest recovery to 3.4 per cent is expected in 2017, growth in Africa will remain well below the average of nearly 6 per cent per annum seen in the years leading up to the global financial crisis.

When viewed in per capita terms, the outlook is particularly bleak, with GDP per capita growth expected to average just 0.4 percent from 2015-2017. The ongoing political turmoil in Libya has pushed the oil-reliant economy into a prolonged and deep recession, which continues to restrain growth and adversely affect the political and economic governance in North Africa. Oil pipeline 
destruction activities of the militants in the Niger Delta region of Nigeria have further ground the country's economy. Security concerns like that of Nigeria's Boko Haram and others like Egypt and Tunisia remain elevated across much of the region, with a severe impact on the tourism sectors, although some improvements are emerging. Security issues are becoming increasingly widespread across other African regions as well, dampening confidence across parts of Central, East and West Africa.

Updates as of mid-2016 indicating the downward revision to economic prospects in Southern Africa reflect the deterioration of commodity prices, the severe drought wrought by El Niño, and inflationary pressures from widespread currency depreciation. Severe drought has also swept across Ethiopia and parts of Somalia in East Africa, while parts of North Africa, have also suffered from drought conditions. In West Africa, economic growth in the small economies of Guinea, Liberia and Sierra Leone is expected to bounce back noticeably in 2016 after the Ebola epidemic. However, the region's larger economies continue to face difficulties posed by low commodity prices. Central Africa is dominated by heavily oil-reliant economies, which can be expected to suffer further export losses in 2016.

With inflationary and currency pressures rising across much of Africa, central banks in Angola, Egypt, Gambia, Ghana, Kenya, Malawi, Mozambique, Namibia, Nigeria, South Africa and Zambia have increased their policy rates in recent months. This is in contrast to the moves in Botswana, Cabo Verde, Morocco, Tunisia and the currency unions of Central and West Africa, which have been more closely aligned with monetary policy in the euro area. This widening divergence of rates of return within Africa can be expected to drive shifts in capital flows and further currency pressures in the region this year. Governments require new sources of revenue to respond to mounting fiscal pressures from weak growth, lost commodity-related revenue and rising expenditure to combat weather-related crises.

Several African countries have issued dollar-denominated debt since the global financial crisis. While this has allowed them to borrow at much lower interest rates, it has also exposed them to currency risk. These risks have materialized in countries such as Angola, Ghana, Namibia, the United Republic of Tanzania and Zambia, where currencies have lost up to 50 per cent of their value since 2014, doubling debt servicing costs on foreign-currencydenominated debt. In the global economic front, China's and India's economies are evolving while America shrinks. The balance of economic power is shifting seriously. After almost a century of dominance, the US economy has gone down the growth rankings, and its influence over the global economy is decreasing. Economic growth in Europe is also slow and fragile. Yet many nonOECD countries - particularly China and India - are enjoying sustained economic growth. Global economic shifts will have a significant influence over 
international politics and governance. They will also have a cascading impact on the other trends shaping our world, such as the growth of the middle class, increasing inequality, and the role and influence of global governance and business in society.

Conspicuously, in 2014, the Chinese economy overtook the United States economy to become the largest in the world, according to one measure (Market Watch, 2014). China now accounts for $16.5 \%$ of the global economy when measured in real purchasing-power terms, compared with $16.3 \%$ for the US. It was expected in 2015 for India to overtake Japan as the world's third largest economy. China is already competing with other countries to lead the world in environmental sustainability. In 2009 it outpaced the US in terms of clean energy investments and finance for the first time; its total investment reached \$34.6 billion, almost double that of the US's \$18.6 billion while in March 2014 China led the US on clean energy investment for the fourth time in five years.

\section{$5 \quad$ Way Forward for Africa's Economic Recovery}

For Africa to survive this present economic crisis, recover from it and sustain its economy, a lot has to be done in the area of policy formulations and manpower development through concerted effects geared towards human resources development and training at all levels offered through education. The policies should be such that will reposition and improve infrastructure, transport, trade relationships, market mix, investments and general quality education across all levels. As contained in his article, Higher Education in Africa Needs Reforms, Alex Awiti stated that; "To educate the next generation for a globalized knowledge economy, we must depart from modes of teaching and learning that rely solely on didactic approaches, which only demand regurgitation from students. To educate the next generation for a globalized knowledge economy demands that we embrace new approaches that are consistent with contemporary views of epistemology and learning theory, which treat knowledge as co-constructed by the student and the professor. Such approaches will demand of students, analytical reasoning, critical thinking and problem solving skills as well as reflective practice, innovation and entrepreneurship."

Suffices it to say that, quality education is a vital key to economic development. That being the case, for us to compete favourably as a region with others, we must firstly embrace education as quality education is a strong predictor of the economic growth rate of any nation. Therefore functional and quality education is not just a necessity for survival but a must acquire. The mismatch between the skills graduates acquire and, local and global workforce 
demand must be addressed. It is true that there is a remarkable improvement in the pupils/students enrolment across all levels but, it should be note that there is still much to be done as it only improved the literacy rate but did not yield the needed manpower/ human resources result needed for global competitiveness. Africa needs to develop a strong curriculum (especially at the tertiary levels where students are finally prepared the job market) for a knowledge and skill based economy which will result in huge socio - economic benefits and bridge the unemployment gap as it is estimated that 11 million youths are expected to enter job market each year. If this is the situation now, should we as Africans fold our arms and watch or should we confront and address our challenges as nobody else will do that for us. Are we ready to achieve Sustainable Development especially Goals 4, 5 and 8 and others by 2030? What about the Education for Sustainable Development (which includes as documented by UNESCO:

1. First, "by 2030 ensure all learners acquire knowledge and skills needed to promote sustainable development, including among others through education for sustainable development and sustainable lifestyles, human rights, gender equality, promotion of a culture of peace and non-violence, global citizenship, and appreciation of cultural diversity and of culture's contribution to sustainable development".

2. Second to "ensure that people everywhere have the relevant information and awareness for sustainable development and lifestyles in harmony with nature" by 2030 .

3. And finally, to "improve education, awareness raising and human and institutional capacity on climate change mitigation, adaptation, impact reduction, and early warning" in order to help combat climate change)?

If the answer yes, what should then be done? A close look at these gives us a clear indication that Africa as a continent has a lot resting on its shoulders to be one of the top players in the global economy. In 2007, a Conference of Ministers of Education of the African Union (COMEDAF) meeting was held in Addis Ababa on how to revive Technical and Vocational Education and Training (TVET) in Africa and it was accepted as the answer to acquiring entrepreneur, technical and vocational skills that will promote African development. Therefore, massive investment in quality education, Teachers training and human capital development should be embarked on. School curricular must be designed in a way to solve our socio - economic problems by enhancing youths' creativity, critical thinking ability, technological skills and other related abilities that will propel them to make their own contributions to African development. Now the big question comes in. Can the government alone do this with the rate of population growth and financial gap and our political system? Of course, the answer is no. The government alone cannot 
meet up with the masses needs. Private Sector participation in the provision of quality standard education that is well coordinated and monitored becomes inevitable here.

\section{Private Sector Participation in Education and Africa's Recovery}

Between 2000 and 2010, Africa was among the six fastest growing economy in the whole world. Africa's population is growing at an alarming rate. The rise in African population will definitely trigger off massive economic development that will come from economic diversification agriculture, manufacturing, tourism, high technological-based industries, banking, telecommunication, extraction, etc. to attract foreign investments in the continent which has already been on the increase in the past ten years. To accomplish this, education and training which has been the continent's major challenge has to be improved on to produce the needed highly skilled and well trained workforce that will help in economic recovery. This means that meeting African needs is a function of high quality education and human capacity building that is in compliant with the $21^{\text {st }}$ century global demand over the next decade. But illiteracy is on the high side in Africa. It estimated that $80 \%$ of South Africa's public schools are underperforming (South Africa's National Planning Commission).

We know that the story is not different in other African countries like, Nigeria, Kenya, Tanzania and Uganda where most of the public school pupils lack the basic skills expected of them. This poor performance across the continent is a matter of great concern to all and sundry. As we all know, the poor performances has its roots from various causes which range from poor and dilapidating infrastructure, inadequate funding, large class sizes, teachers' low salaries, insufficient and inadequate school supplies, incessant teachers' strikes, bureaucratic bottlenecks to non-quality teaching and learning methodology. Also, ESSPIN report pinpointed yet inadequate funding, and incessant teachers' strike to quality of instruction as some of the challenges of public schools. Notably, Africa needs a massive increase in educational capacity development and training. "The demand for educational services in Africa is rising at a faster rate than the governments can supply" (World Bank, 2010). Therefore, for Africa to reach the expected level of development that will culminate into economic recovery, private education participation has to come in to fill in the gap.

The number of private schools across Africa for primary and secondary education continues to rise. In a UNESCO survey of 25 African countries, the proportion of private primary schools increased from 9 percent to almost 10 
percent between 2000 and 2008. As at 2009, there were around 200 public universities and 468 private higher education institutions on the African continent. Enrolment in private schools at all levels is fast increasing in throughout Africa continent - primary, secondary and tertiary levels. Does this increase meet the continent's education needs? If more than 30 million primary and 90 million secondary school children are currently out of school system, limited gains over the last 25 years in literacy rate across the continent from 53$60 \%$ with rapidly increasing population and funding gap of over US \$1 trillion, it is a clear indication indeed that the governments alone cannot provide the educational needs of the teaming population and take us to the desired economic position in the global map hence, there is an urgent need for rescue from economic crisis by private sector participation to relieve the various governments of the continent that have been badly squeeze to the bones. Parents as we all know, want the very best for their children as education is seen as the road to a better livelihood. Private schools are nearly outnumbering the number of public schools, responding rapidly to global and community needs.

Africans is competing in a global and skill - based job market, therefore improving access to quality education must be our priority to foster sustainable economic development. If 48 million African youths (ages 15-24) are illiterate (UNESCO), do we not need a drastic measure to go low on this number? Already, private schools are making major contributions to economic recovery through education. In recent years, parents and organizations began to question the credibility of public schools and the credentials got from such schools. Going by this, private schools became a choice favourite for parents despite the high fee charged. Do private schools really have an impact on Africa's economic recovery and how? The answer is yes.

The role and benefits of private schools over public schools in emerging economy cannot be overemphasized. There are no bureaucratic delays in private schools hence they make huge investments as at when due and the need arises. They show a comparative advantage in educational achievements over public schools at the same low cost. According to World Bank Study, WDP309, Dec 1995; Public and Private Secondary Education in Developing Countries, for the same cost per pupil, private schools in five participating countries (Colombia, Dominican Republic, Philippines, Tanzania and Thailand) performed $1.2-6.7$ times better than public schools in terms of achievements in Language and Mathematics. This explains that there is better learning and teaching outcomes in private schools. $21^{\text {st }}$ century technology - based teaching and learning is globally making waves now. Private schools with their readiness to invest and build on quality, bring in innovations in the classrooms, develop teaching models, set up virtual classrooms for students to learn even when they are far away from schools, interactive e - learning and teacher - created videos 
watched online. Even if the students are miles away, as the world is becoming more global and closer together, they can learn via e - lessons. With this the students can access education from anywhere. Private schools offer more blended and integrated or fused curriculum for globalization taught by closely monitored team of professionals under the supervision of the various ministries and agencies that approved them.

In other words, the private sector does not compromise standard and quality as huge amount of money is invested on infrastructure, supplies, training, etc. If we take the current Nigeria's new Senior Secondary School Curriculum that brought in Trade and Entrepreneurship subjects as an example, more private schools are investing huge amount of money on laboratories, workshops and equipment than public schools. Most private schools in Africa have even gone beyond their country's curriculum and took up other curricula like Cambridge, American curriculum, SAT, Edexcel, International Baccalaureate and the likes to prepare their students for global competitiveness as they cannot afford to fail the parents who are investing much in their children's future. Of course, it is known that over decades, private sector participation in any aspect of any country's economy plays a crucial role of timely rescue in times of crisis as is the case with healthcare, banking, etc. Therefore, private education participation will help immensely in Africa's economic recovery, transformation and sustenance.

\section{References}

Market Watch (2014). It's Official: America is now No.2. Retrieved from: http://www.marketwatch.com/story/its-official-america-is-now-no-2-201412-04.

Ohanyido, C. (2014). The Pivotal Role of Education in Africa's Development. Retrieved from: http://www.globaleducationconference.com.

Oni, T. (2004). Financing education in sub-Saharan Africa-Meeting the Challenges of Expansion, Equity and Quality. Retrieved from: http://en.unesco.org: UNESCO.

Onyeani, C. (2005). Intellectual Bankruptcy of the African Elite. Retrieved from: http://www.gamji.com/article4000/NEWS4903.htm.

UNESCO (2010). Education Counts: Towards the Millennium Development Goals. Retrieved from: http://unesdoc.unesco.org/images/0019/001902/190214e.pdf.

UNESCO (2014). Sustainable Development: Post-2015 begins with Education. Retrieved from: //unesdoc.unesco.org/images/0023/002305/230508e.pdf. 
United Nations (2016). World Economic Situation and Prospects 2016. Retrieved http://www.un.org/en/development/desa/policy/wesp/wesp_current/2016wes p_update.pdf.

Watkins, K. (2013). Too little access, not enough learning: Africa's twin deficit in education. Retrieved from: http://www.brookings.edu/research/opinions/2013/01/16-Africa-learningwatkins.

World Bank (2010). Population Projections, Global Campaign for Education Report 2010; UNESCO Education for All 2011 - Facts and Figures; School Choice (2013). Department for International Development. Lagos

World Economic Situation and Prospects (2016). http://www.globalpolicywatch.org. 